\title{
Covid-19: how to be careful with trust and expertise on social media
}

\author{
At times of crisis we turn to experts-but news outlets and social media must be careful about the \\ information they share, particularly informally, writes Sue Llewellyn
}

\section{Sue Llewellyn}

London

Three times in one day I received the same warning from different groups of friends, through various channels. It came through email, Facebook, and WhatsApp, and I also saw it circulating widely on Twitter. I replied thanking them, saying that I knew they wanted to help (we all do) but that, actually, the warning wasn't true and could even be dangerous. I felt almost unkind by pointing out that holding your breath wasn't a test for covid-19. And that drinking lots of water wouldn't help it go away.

These viral warnings always start the same way. A doctor/nurse/specialist health or government worker-often, apparently, a friend or relative-shares a warning or advice of some kind. This often sounds credible and sometimes may even have a kernel of truth, but it almost always provokes some emotional response in the reader. Fear and outrage are the most contagious.

The desire to protect loved ones means that it's difficult not to share these messages—we want to be helpful—but it's crucial that we stop and think before doing so. Like the coronavirus itself, we should be thinking about contact tracing: who sent the message, what's the original source, and how do I know it to be true?

I'm a former BBC journalist who, after 15 years working in the newsroom, became a social media consultant and trainer in 2008. After introducing Twitter to the BBC newsroom I've since trained over 6000 people in how to use social media effectively and safely, including thousands of journalists, government officials, GPs, sportspeople, non-governmental organisations, and businesses around the world. I always emphasise that it's vital to understand the psychology of social media if we're to conquer the spread of disinformation. Especially in a crisis such as this one.

\section{Stories and rumours}

This issue of a medic or health professional in authority tweeting advice was again brought into focus last week, when France's health minister, Olivier Véran, tweeted about ibuprofen. ${ }^{1}$ Stories and rumours about this went viral, and the topic became one of the most searched and shared, as people understandably became concerned. The BBC's Reality Check team explained the confusion and warned about other false stories doing the rounds. ${ }^{2}$

We're all looking for answers we don't have right now, but it's crucial to be clear on what we do or don't know. We're living through an info-demic (or disinfo-demic), and we all have a responsibility to each other, whether we're medics or not.

It's important to remember that the media, as well as the public, are constantly all over the social media channels, looking for new angles and experts to share their insight and opinion. They don't know if someone's stepped outside their area of expertise or if a piece of research has been peer reviewed. They may not know that researchers and doctors don't always agree. They don't know whose opinion to trust. But, in times of crisis, trust is the most important thing to consider if you want to communicate health advice.

Claire Wardle, a leading specialist in the spread of disinformation and founder of the First Draft News project, says, "The best way to fight misinformation is to swamp the landscape with accurate information that is easy to digest, engaging, and easy to share on mobile devices. It should also answer people's questions and, ultimately, fears. It's the vacuums that are creating space for rumours to run wild."

We should fill that vacuum by amplifying official, trustworthy sources. We need to be reiterating clear, jargon-free, practical messages that give people tangible steps they can take, such as handwashing, to help them feel more in control.

A Twitter thread by Heidi Tworek, ${ }^{4}$ assistant professor at the University of British Columbia in Canada, makes the point that "communications in a public health crisis are as crucial as medical intervention ... . in fact, communications policies ARE a medical intervention." She goes on to offer a helpful list of practical steps we should all be taking. These include: 
- Don't overload people with information—short, shareable bullet points are far more effective.

- Pairing visuals with text helps us to remember, such as using photos with text, or videos with audio and subtitles.

- Include infographics such as flowcharts, timelines, and Venn diagrams, which all need to work on mobile devices.

- Use fun videos—ask your kids to show you the handwashing dances on TikTok, the video sharing service. These are a great way to reach younger audiences and good for older generations too: Gloria Gaynor ${ }^{5}$ washing her hands to "I Will Survive" is exactly the sort of viral information we need to be spreading.

Lastly, give people hope: we learn best by laughing, and this is exactly the medicine we all need right now.
Competing interests: I have read and understood BMJ policy on declaration of interests and have no relevant interests to declare.

Provenance and peer review: Commissioned; not externally peer reviewed.

1 Véran O. Twitter. $14 \mathrm{Mar} 2020$.https://twitter.com/olivierveran/status/ 1238776545398923264. (In French.)

Coronavirus and ibuprofen: Separating fact from fiction. BBC News 2020 Mar 17. https:/ /www.bbc.co.uk/news/51929628.

Wardle C. Twitter. 17 Mar 2020. https://twitter.com/cward1e/status/1239999802097782785.

4 Tworek H. Twitter. 18 Mar 2020. https://twitter.com/HeidiTworek/status/ 1240340632666701824

5 Gaynor G. It only takes 20 seconds to "SURVIVE!" TikTok. Mar 2020. https://www.tiktok. com/@gloriagaynor/video/6802612178655464710.

Published by the BMJ Publishing Group Limited. For permission to use (where not already granted under a licence) please go to http://group.bmj.com/group/rights-licensing/ permissions 